University of Michigan Law School University of Michigan Law School Scholarship Repository

2001

\title{
Globalization and Tax Competition: Implications for Developing Countries
}

Reuven S. Avi-Yonah

University of Michigan Law School, aviyonah@umich.edu

Available at: https://repository.law.umich.edu/articles/647

Follow this and additional works at: https://repository.law.umich.edu/articles

Part of the Comparative and Foreign Law Commons, Taxation-Transnational Commons, and the Transnational Law Commons

\section{Recommended Citation}

Avi-Yonah, Reuven S. "Globalization and Tax Competition: Implications for Developing Countries." Law Quad. Notes 44, no. 2 (2001): 60-5.

This Article is brought to you for free and open access by the Faculty Scholarship at University of Michigan Law School Scholarship Repository. It has been accepted for inclusion in Articles by an authorized administrator of University of Michigan Law School Scholarship Repository. For more information, please contact mlaw.repository@umich.edu. 


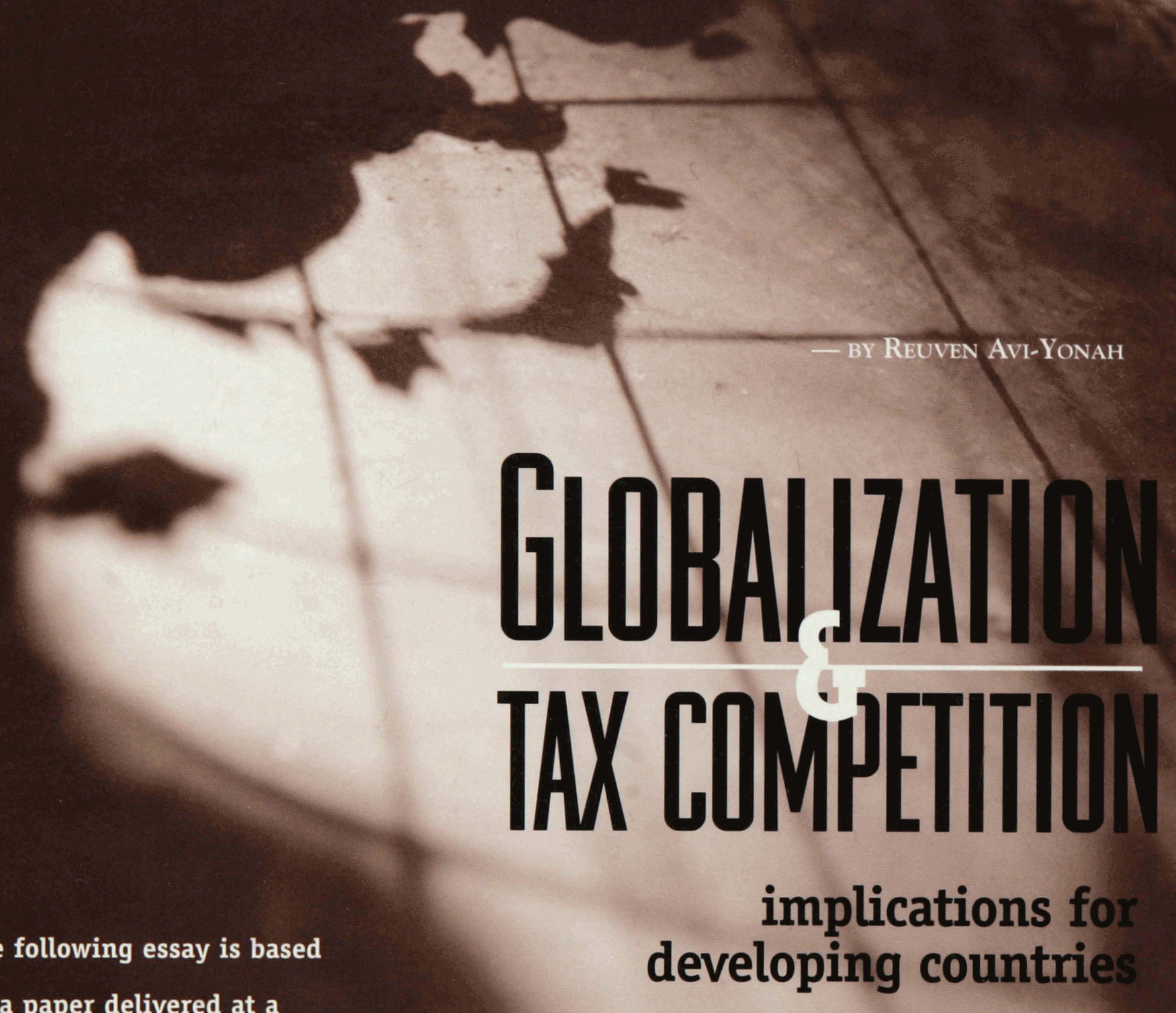

on a paper delivered at a

meeting of the UN Economic

Commission for Latin America

and the Caribbean in

Santiago, Chile, in January.

The current age of globalization can be distinguished from the previous one (from 1870 to 1914) by the much higher mobility of capital than labor (in the previous age, before immigration restrictions, labor was at least as mobile as capital). This increased mobility has been the result of technological changes (the ability to move funds electronically), and the relaxation of exchange controls. The mobility of capital has led to tax competition, in which sovereign countries lower their tax rates on income earned by foreigners within their borders in order to attract both portfolio and direct investment. Tax competition, in turn, threatens to undermine the individual and corporate income taxes, which remain major sources of revenue (in terms of percentage of total revenue collected) for all modern states. 
The response of both developed and developing countries to these developments has been first, to shift the tax burden from (mobile) capital to (less mobile) labor, and second, when further increased taxation of labor becomes politically and economically difficult, to cut government services. Thus, globalization and tax competition lead to a fiscal crisis for countries that wish to continue to provide those government services to their citizens, at the same time that demographic factors and the increased income inequality, job insecurity, and income volatility that result from globalization render such services more necessary.

From its beginnings late in the 19th century, the modern state has been financed primarily by progressive income taxation. The income tax differs from other forms of taxation (such as consumption or social security taxes) in that in theory it includes income from capital in the tax base, even if it is saved and not consumed. Because the rich save more than the poor, a tax that includes income from capital in its base is more progressive (taxes the rich more heavily) than a tax that excludes income from capital (e.g., a consumption tax or a payroll tax). However, the ability to tax saved income from capital (i.e., income not vulnerable to consumption taxes) is impaired if the capital can be shifted overseas to jurisdictions where it escapes taxation.

Two recent developments have dramatically augmented the ability of both individuals and corporations to earn income overseas free of income taxation: the effective end of withholding taxation by developed countries, and the rise of production tax havens in developing countries. Since the United States abolished its withholding tax on interest paid to foreigners in 1984, no major capital importing country has been able to impose such a tax for fear of driving mobile capital elsewhere (or increasing the cost of capital for domestic borrowers, including the government itself). The result is that individuals can generally earn investment income free of host country taxation in any of the world's major economies. Moreover, even developed countries find it exceedingly difficult to effectively collect

\section{G}

competition lead to a fiscal crisis

for countries that wish to continue

to provide those government

services to their citizens, at the

same time that demographic

factors and the increased income

inequality, job insecurity, and

income volatility that result from

globalization render such services

more necessary.

the tax on the foreign income of their individual residents in the absence of withholding taxes imposed by host countries, because the investments can be made through tax havens with strong bank secrecy laws. Developing countries, with much weaker tax administrations, find this task almost impossible. Thus, cross-border investment income can largely be earned free of either host or home country taxation.

For example, consider a wealthy Mexican who wishes to earn tax-free interest income from investing in the bonds of an American corporation. All he needs to do is set up, for a nominal fee, a Cayman Islands corporation to hold the bonds. The interest payments are then made to the Caymans corporation without any U.S. tax withheld under the so-called "portfolio interest exemption" (Internal Revenue Code section 871(h)). The individual does not report the income to the Mexican tax authorities, and they have no way of knowing that the Caymans corporation is effectively an "incorporated pocketbook" of the Mexican resident. Nor are the exchange of information provisions of the U.S.-Mexico tax treaty of any help, because the IRS has no way of knowing that the recipient of the interest payments is controlled by a Mexican resident and therefore cannot report this to the Mexican authorities. As a result, the income is earned completely free of tax (the Caymans, of course, impose no income taxes of their own).

When we switch our attention from passive to productive investment, a similar threat to the taxing capacity of both home and host jurisdictions emerges. In the last decade, competition for inbound investment has led an increasing number of countries (103, as of 1998) to offer tax holidays specifically geared to foreign corporate investors. Given the relative ease with which an integrated multinational can shift production facilities in response to tax rates, such "production tax havens" enable multinationals to derive most of their income abroad free of host country taxation. Moreover, most developed countries (including the United States) do not dare impose current taxation (or sometimes any taxation) on the foreign source business income of their resident multinationals, for fear of reducing the competitiveness of those multinationals against multinationals of other countries. If they did, new multinationals could be set up as residents of jurisdictions that do not tax such foreign source income. Thus, business income can also be earned abroad largely free of either host or home country taxation.

For example: Intel Corporation, a top 10 multinational, has operations in more than 30 countries around the globe. The company states that "[a]n Intel chip developed at a design center in Oregon might be manufactured at a wafer fabrication facility in Ireland, packaged and tested in Malaysia, and then sold to a customer in Australia. Another chip might be designed in Japan, fabricated in Israel, packaged and tested in Arizona, and sold in China." Specifically, outside the United States, Intel has major manufacturing facilities in Puerto Rico, China, Malaysia, the Philippines, Ireland, and Israel. Thus, outside the United States, all of Intel's manufacturing facilities are located in countries granting tax holidays. Nor does Intel pay current U.S. tax on its income from those foreign operations, because under U.S. law, active income earned by foreign subsidiaries of U.S. multinationals is not taxed until it is repatriated in the form of dividends, which Intel can delay for many years. Thus, the effective tax rate on Intel's foreign source income is far below the nominal U.S. corporate rate of 35 percent. 
If income from capital can escape the income tax net, the tax becomes in effect a tax on labor. Several empirical studies have in fact suggested that in some developed jurisdictions the effective tax rate on income from capital approaches zero, and tax rates on capital have tended to go down sharply since the early 1980s (when exchange controls were relaxed). As a result, countries that used to rely on the revenues from the income tax are forced to increase relatively regressive taxes.

The two fastest growing taxes in OECD (Organization for Economic Cooperation and Development) member countries in recent years have been consumption taxes (from 12 percent of total revenues in 1965 to 18 percent in 1995) and payroll taxes (from 19 percent to 27 percent), both of which are more regressive than the income tax. Over the same period, the personal and corporate income taxes have not grown as a percentage of total revenues (the personal income tax accounted for 26 percent of total revenues in 1965 and 27 percent in 1995, while the figures for the corporate income tax are 9 percent and 8 percent respectively). The total tax revenue as a percentage of GDP (Gross Domestic Product) in developed countries went up sharply during the same period (from an average of 28 percent in 1965 to almost 40 percent in 1994), and this increase is largely accounted for by the rise of consumption and payroll taxes. Moreover, there is evidence that as the degree of openness of an economy in OECD member countries increases, taxes on capital tend to go down while taxes on labor go up (the income tax is imposed on both capital and labor, so that its stability may mask this trend).

The same trends can be observed in developing countries as well. In nonOECD member countries (outside the Middle East) total government revenues as a share of GDP rose from an average of 18.8 percent in $1975-80$ to 20.1 percent in 1986-92. This growth was financed primarily by the growth of revenues from the VAT in the same period (from 25.5 percent of total revenues to 31.8 percent). At the same time, revenues from both the individual and the corporate income tax were flat or declined.

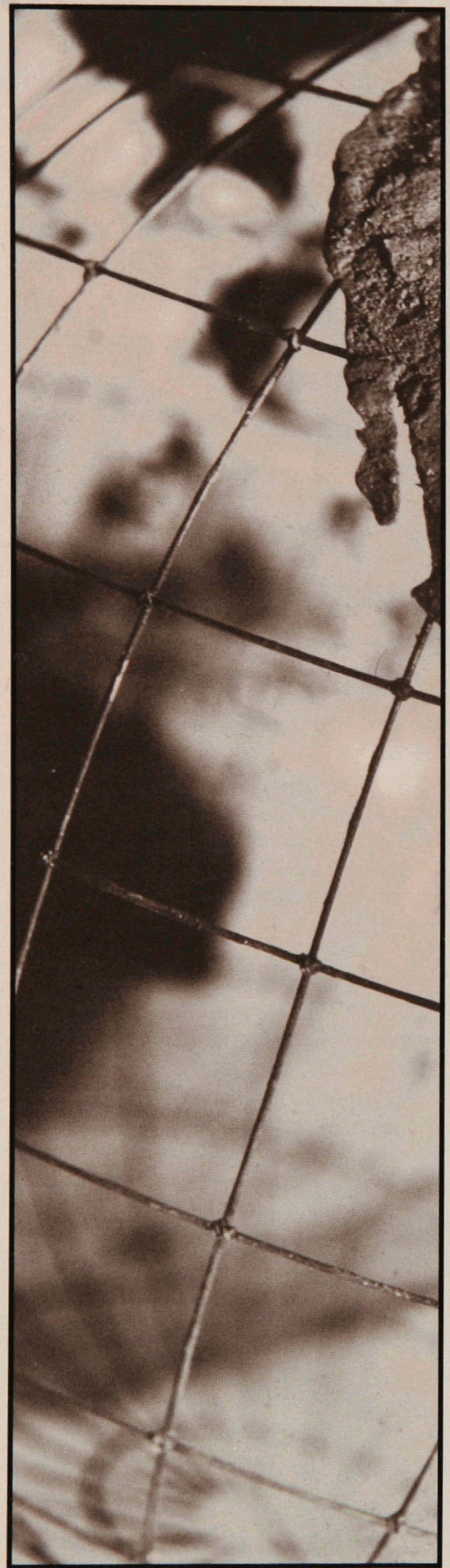

\section{TAX COMPEITITON AND THE DEVELPNNG CUNTRRIES}

The drawbacks of tax competition for developed countries are relatively clear, because such countries have an elaborate social insurance safety net that requires a high level of government expenditure and that is threatened by tax competition. But how does tax competition affect developing countries?

First, it should be pointed out that developing countries need the revenues at least as much as developed countries do, if not more. A common misperception is that only OECD member countries are confronted by a fiscal crisis as a result of the increasing numbers of elderly people in the population. In fact, the increase in dependency ratios (the ratio of the elderly to the working population) is expected to take place in other geographic areas as well, as fertility rates go down and health care improves. Outside the OECD and the transition economies, the dependency ratio starts in the single digits in the 1990s, but rises to just below 30 percent by 2100 . Moreover, while outside the OECD and the transition economies direct spending on social insurance is much lower, other forms of government spending (e.g., government employment) effectively fulfill a social insurance role. In Latin America, for example, direct government spending on social insurance is much lower than indirect spending through government employment and procurement programs.

Moreover, it seems strange to argue that developing countries need tax revenues less than developed countries because they have less developed social insurance programs. If one accepts the normative case for social insurance, it applies to developing countries with even greater force because of widespread poverty, which means that losing a job can have much more dire consequences. But the need for revenues in developing countries goes far beyond social insurance. In some developing countries revenues are needed to insure the very survival of organized government, as the Russian experience 
demonstrates. In other, more stable developing countries, revenues are needed primarily to provide for adequate education (investment in human capital), which many regard as the key to promoting development. For example, the UN has estimated that for only $\$ 30-\$ 40$ billion, all people in the world can obtain basic social services (such as elementary education). Given current trends in foreign aid, most of these funds have to come from developing country governments.

Second, the standard advice by economists to small open economies is that they should refrain from taxing foreign investors, because such investors cannot be made to bear the burden of any tax imposed by the capital importing country. Therefore, the tax will necessarily be shifted to less mobile factors in the host country, such as labor and/or land, and it is more efficient to tax those factors directly. But while this argument seems quite valid as applied to portfolio investment, it seems less valid in regard to FDI (foreign direct investment, i.e., investment by multinational enterprises), for two reasons. First, the standard advice does not apply if a foreign tax credit is available in the home country of the investor, which frequently would be the case for FDI. Second, the standard advice assumes that the host country is small. However, an extensive literature on multinationals suggests that typically they exist in order to earn economic rents. In that case, the host country is no longer "small" in the economic sense. That is, there is a reason for the investor to be there and not elsewhere. Therefore, any tax imposed on such rents (as long as it is below 100 percent) will not necessarily drive the investor to leave even if it is unable to shift the burden of the tax to labor or landowners.

This argument clearly holds in the case of rents that are linked to a specific location, such as natural resources or a large market. But what if the rent can be earned in a large number of potential locations? In this case, the host country will not be able to tax the rent if the multinational can credibly threaten to go elsewhere, although once the investment has been made the rent can be taxed. This situation, which is probably the most common, would require coordinated action to enable all host countries to tax the rent earned within their borders. Some possibilities for such action are described below. This relates to the final argument, which is that host countries need to offer tax incentives to be competitive. An extensive literature has demonstrated that taxes do in fact play a crucial role in determining investment location decisions. But all of these studies emphasize that the tax incentives are crucial given the availability of such incentives elsewhere. Thus, it can be argued that given the need for tax revenues, developing countries would in general prefer to refrain from granting tax incentives, if only they could be assured that no other developing country would be able to grant such incentives.

Thus, restricting the ability of developing countries to compete in granting tax incentives does not truly restrict their autonomy or counter their interests. That is the case whenever they grant the incentive only for fear of competition from other developing countries, and would not have granted it but for such fear. Whenever competition from other countries drives the tax incentive, eliminating the competition does not hurt the developing country, and may aid its revenue raising efforts (assuming it can attract investment on other grounds, which is typically the case). Moreover, under the proposals described below, developing countries remain free to lower their tax rates generally (as opposed to granting specific tax relief aimed at foreign investors).

Two additional points need to be made from a developing country perspective. The first concerns the question of tax incidence. Since the tax competition that is most relevant to developing countries concerns the corporate income tax, it is important to attempt to assess the incidence of that tax in evaluating the effects of collecting it on the welfare of the developing country. Unfortunately, after decades of analysis, no consensus exists on the incidence of the corporate tax. While the older studies have tended to conclude that the tax is borne by shareholders or by all capital providers, more recent studies have suggested that the tax is borne to a significant extent by consumers or by labor. Another possibility is that the tax on established corporations was borne by those who were shareholders at the time the tax was imposed or increased, because thereafter it is capitalized into the price of the shares. It is unlikely that this debate will be decided any time soon (in fact, the incidence may be shifting over time, especially as globalization may enable corporations to shift more of the tax burden to labor).

However, from the perspective of a developing country deciding whether to collect taxes from a multinational, three out of the four possible alternatives for incidence (current shareholders or capital providers, old shareholders, and consumers) are largely the residents of other jurisdictions, and therefore from a national welfare perspective the developing country gains by collecting the tax. And even if some of the tax is shifted to labor in the developing country, it can be argued that as a matter of tax administration it is more efficient (as well as more politically acceptable) to collect the tax from the multinational than to attempt to collect it from the workers.

Finally, it should be noted that a developing country may want to collect taxes from multinationals even if in general it believes that the private sector is more efficient in using the resources than the public sector. That is because in the case of a foreign multinational, the taxes that the developing country fails to collect may indeed be used by the private sector, but in another jurisdiction, and therefore not benefit the developing country. One possible solution, which is in fact employed by developing countries, is to refrain from taxing multinationals while they re-invest domestically, but tax them upon remittance of the profits abroad. However, such taxation of dividends and other forms of remittance is subject to the same tax competition problem that we discussed above. Thus, it would appear that overcoming the tax competition problem is in most cases in the interest of developing countries, and the question remains how to do so in the face of the collective action problem described above. 


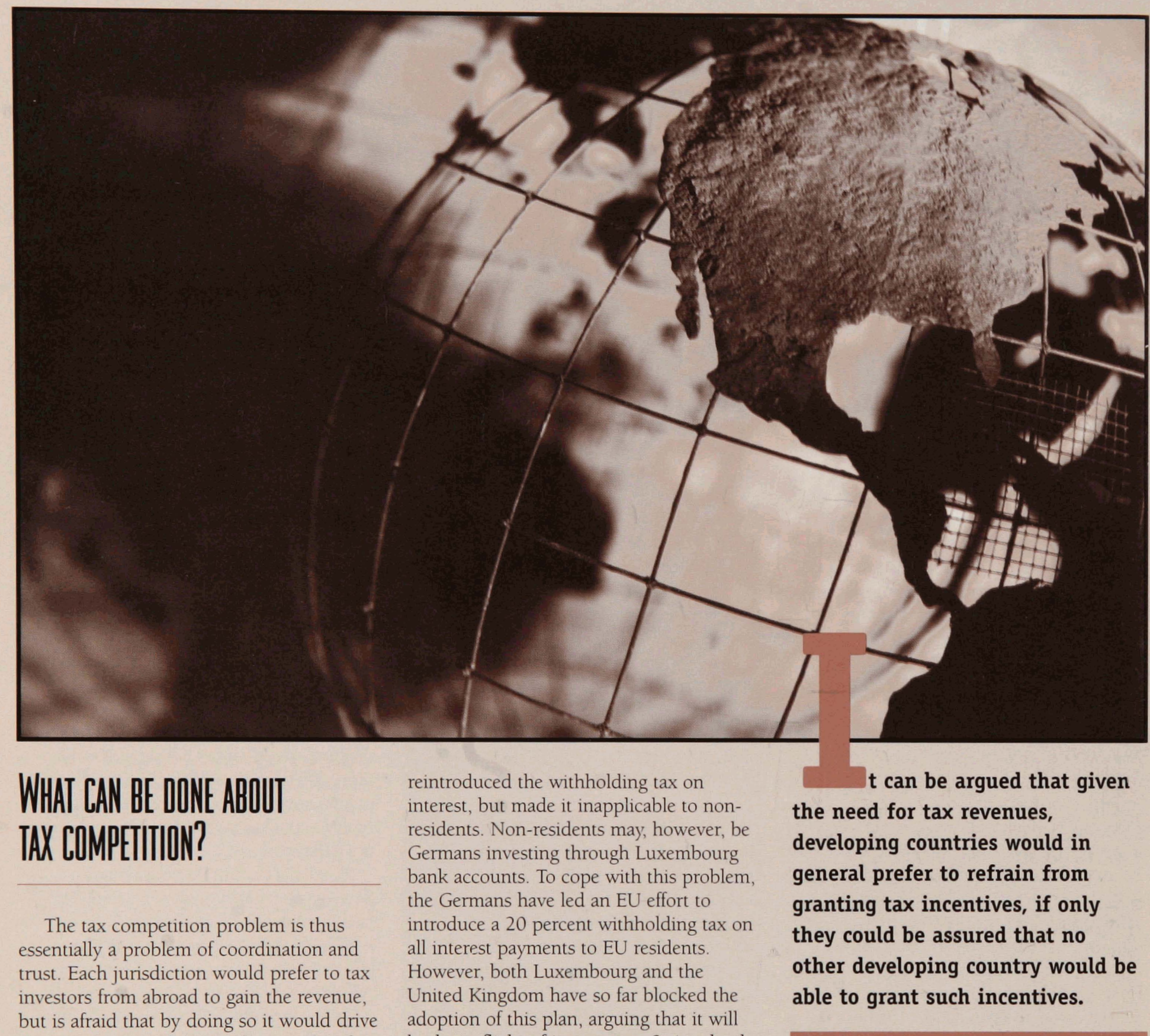
the investors to other jurisdictions that do not tax them. If there were a way to coordinate actions among the relevant jurisdictions, they all could gain added revenues without running the risk of losing the investment.

A good illustration of how this dynamic works is the history of German taxation of interest income. In 1988, Germany introduced a 10 percent withholding tax on interest paid to bank depositors, but had to abolish it within a few months because of the magnitude of capital flight to Luxembourg. In 1991, the German Federal Constitutional Court held that withholding taxes on wages but not on interest violated the constitutional right to equality. The government thereupon lead to a flight of investors to Switzerland or the United States.

Thus, the key to finding a solution to the tax competition problem is to attack it on a broad multilateral basis, through an organization such as the OECD. Under current conditions, the OECD is the natural choice for leading such coordinated actions against tax competition, for three reasons. First, for individual investors to earn decent returns on their capital without incurring excessive risks, they need to invest in an OECD member country. Tax havens do not offer adequate investment opportunities, and developing countries are generally considered too risky for portfolio investment (other than through mutual funds, which do not offer tax avoidance opportunities). Thus, if all OECD members 
enforced taxation of portfolio investment, it could be subject to tax without requiring cooperation from the tax havens.

Second, about 85 percent of the world's multinationals are headquartered in OECD member countries. This is likely to continue to be the case for a while, because OECD members offer stable corporate and securities law protection to investors that is lacking in other countries. Thus, if all OECD members agreed on a coordinated basis to tax their multinationals currently on their income from abroad, most of the problem of tax competition from direct investment could be solved.

Third, the OECD has the required expertise (its model tax treaty is the global standard) and has already started on the path of limiting tax competition. In 1998, it adopted a report entitled Harmful Tax Competition: An Emerging Global Issue. This report is somewhat limited, because it only addresses tax competition for financial activities and services (as opposed to, e.g., Intel's manufacturing plants). It also does not address the taxation of investment income. But it represents an extremely useful first step, and proof that a consensus can be reached on the tax competition issue. (Switzerland and Luxembourg abstained, but did not dare veto the adoption of the report by the other 27 members of the OECD.)

The OECD makes a useful distinction between tax competition in the form of generally applicable lower tax rates, and tax regimes designed to attract foreign investors. This distinction is both normatively and pragmatically sound: Restricting tax competition should not and cannot mean that voters in democratic countries lose their right to determine the size of the public sector through general tax increases or reductions. But it does mean that countries should not provide windfalls for foreign investors at the expense of the ability of other countries to provide those public services their residents desire. Such limitations are particularly appropriate because those foreign investors themselves often reside in countries providing a high level of services, and yet refuse to pay the tax price that providing such services entails.
Depending on the OECD for solving the tax competition problem suffers from one major drawback: Developing countries are left out, and may perceive actions by the OECD as a cartel of rich countries operating at their expense. In fact, as pointed out above, it is unlikely that tax competition benefits developing countries, who can also use the tax revenues they give up to attract foreign investors. If all developing countries could be prevented from competing in this fashion, they all could gain. But in the longer run, it may be better to entrust the fight against harmful tax competition to the WTO, in which developing countries are adequately represented. This would also solve the problem of what to do about the 15 percent of multinationals who are not headquartered in OECD member countries (a percentage that can be expected to grow if the OECD indeed moves to restrict tax competition for its multinationals).

To sum up: As a result of globalization and tax competition, tax rules can no longer be set by countries acting unilaterally or by bilateral tax treaties. In a world in which capital can move freely across national borders and multinationals are free to choose among many investment locations, the ability of any one country (or any two countries in cooperation) to tax (or otherwise regulate) such capital is severely limited. Any such unilateral attempt will be undercut by other countries, and will probably not even be attempted in the name of preserving national competitiveness. Thus, a multilateral solution is essential if the fundamental goals of taxation or other regulation are to be preserved. Private market activities that span the globe can only be regulated or taxed by organizations with a similar global reach.

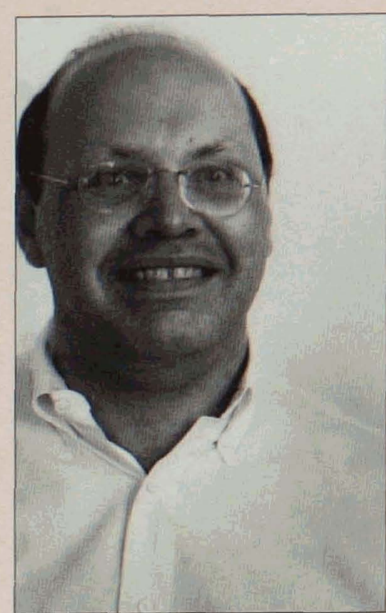

Reuven S. Avi-Yonah earned his B.A. in history, summa cum laude, from Hebrew University, and then continued his education at Harvard University. Ultimately, he received three degrees from Harvard: an A.M in history, a Ph.D. in history, and a J.D., magna cum laude, from Harvard Law School. Professor Avi-Yonah's teaching experience is extensive. Before joining the permanent faculty at the University of Michigan Law School, he had been a visiting professor of law at the University of Michigan Law School and the University of Pennsylvania. He also has served as an assistant professor of law at Harvard Law School and as an assistant professor of history at Boston College. In addition, he has practiced law with Milbank, Tweed, Hadley \& McCloy, New York; Wachtell, Lipton, Rosen E Katz, New York; and Ropes E Gray, Boston; and has co-chaired several committees of the New York State Bar Tax Section and served as a member of the U.S. Income Advisory Board for Tax Management since 1995. In addition to English, Professor AviYonah is fluent in French, German, and Hebrew, and reads in Arabic, Greek, Italian, Latin, Portuguese, and Spanish His teaching interests focus on various aspects of taxation and multinational enterprise. He has written extensively on national and international tax issues. Professor Avi-Yonah's research currently focuses on the interaction of tax and trade law. 